\title{
Language Acquisition Learning to Reduce Interference
}

\author{
Melia Sri Rahayu ${ }^{1, *}$ Syahrul Ramadhan ${ }^{2}$ \\ ${ }^{1}$ Postgraduate Students of Indonesian Language and Literature Education, Universitas Negeri Padang \\ ${ }^{2}$ Indonesian Language and Literature Education, Universitas Negeri Padang \\ *Corresponding author Email: meliasrirahayu462@gmail.com
}

\begin{abstract}
Language is used as a means of communication to convey intentions, ideas, thoughts, ideas, and findings. Language has been acquired by humans from the age of five from the mother (mother tongue) or better known as the acquisition of the first language. The acquisition of children's language will develop from acquiring the first language to the acquisition of a second language. Language acquisition learning has been learned accidentally and deliberately (from mothers and the environment). Indonesian language acquisition learning has been studied starting from elementary school to college. However, there are still many interventions carried out by students and students. Therefore it is necessary to increase the knowledge of language acquisition learning to reduce interference among students. This study aimed was to determine students' language acquisition learning to reduce interference. The method used in this research is descriptive which is not bound by the place of researc because the object of research is in the form of texts (texts) from several national and international journals. The results showed that there was a lot of interference among students both inside and outside the classroom. This interference cannot be considered minor because aspects of language competence are very necessary for a person's life. The concept of language acquisition states that we have to get used to correct sentences. Don't justify wrong sentences either verbally or in writing. Thus, language acquisition learning greatly determines the language competence of students.
\end{abstract}

Keywords: Acquisition learning, and interference

\section{INTRODUCTION}

Every country in the world has a language that is different from other countries. Language is used as a means of communication to convey intentions, ideas, thoughts, ideas, and findings. Language aims to be able to interact between fellow individuals. Language exists in written, spoken, and symbolic forms that are easily understood and understood by the two communicating parties. Language has been acquired by humans from the age of five from their mother (mother tongue) or better known as first language acquisition. Language acquisition is a human process of gaining the ability to capture, produce, and use words so that good communication occurs [1]. Acquisition of the first language occurs naturally when children learn the language from their mother [2]. Language acquisition in children needs to be developed to improve their communication skills. At the age of fewer than five years, the children's language process begins to develop like adult language. Children's language development is one of the sequences of children's growth in addition to gross motor development, fine motor development, and social development [3]

The development of language acquisition is generally used as an indicator of a child's level of intelligence. A child is said to be intelligent if the child can solve visionmotor problems, is fluent in the language, and can socialize. The acquisition of children's language will continue to develop along with the development and age of the child. Children's language acquisition will develop from first language acquisition to second language acquisition. Acquisition of a second language is the language obtained after acquiring the mother tongue (native language). A child's second language acquisition can be obtained from his environment, such as at school. At school, children learn English or Arabic, which is not their native language. It is easier for children to learn a second language than adults who also learn the same language [4]

Language acquisition learning has been learned accidentally and deliberately (from mothers and the environment). Indonesian language acquisition learning 
has been studied from elementary school to university. However, there are still many interventions carried out by students and students. Students do a lot of interference both orally and in writing. Students should be skilled in using Indonesian in an academic environment. Therefore it is necessary to increase the knowledge of language acquisition learning to reduce interference among students. The purpose of this study was to review students' language acquisition learning in reducing interference. It is hoped that language acquisition learning can improve and develop student competencies in speaking Indonesian properly and correctly.

\section{METHODS}

The method used in this research is descriptive which is not bound by the place of research, because the object of the research is in the form of texts from several national and international journals [5]

\section{RESULTS AND DISCUSSION}

Acquisition of the first language occurs naturally when children learn the language from their mother. Language acquisition is a human process of gaining the ability to capture, produce, and use words so that good communication occurs [1]. The development of language acquisition is generally used as an indicator of the level of intelligence of children. According to [6], language is universal, which means that languages all over the world are the same, what distinguishes them is the variation of each language. For example, Americans use English to communicate, Indonesians use Indonesian.

The migration of a population in society can lead to changes in the linguistic situation. The language acquisition capacity includes various abilities such as syntax, phonetics, and a wide vocabulary. The acquired language can be in the form of vowels as in spoken language or sign language. Acquisition of the first language examines the acquisition of children in their mother tongue and acquisition of the second language which examines the acquisition of additional language by children or adults. There are three theories of how children acquire language, namely behavioristic, nativistic, and cognitivist language acquisition theories. The behavioristic theory states that language acquisition in children comes from the surrounding environment. The nativistic theory states that children acquire and develop language skills because children have innate language faculty or better known as the Language Acquisition Device [7]. The cognitive theory explains the acquisition of language as a result of mental work and cognitive abilities of children in discovering language structures through their surroundings. The cognitive theory states that nature and organisms are an inseparable functional units [8] Acquiring good language since childhood will support the quality of human life, especially in the aspect of social interaction towards acquiring a second language [9]

Language is the object of linguistic study and can be different from language, is a human activity in producing and perceiving language. There are several stages of the language process, namely semantic encoding, grammatical encoding, and phonological encoding. Semantic encoding and grammatical encoding take place in the brain. Phonological encoding begins in the brain and is then responded to by speech instruments that involve the nervous system of the brain, speaking from the throat muscles, tongue muscles, lips, mouth, palate, nasal cavity, vocal cords, and lungs [10]. Speaking is the process of removing thoughts and feelings (from the brain) orally, in the form of words or sentences. Language can be understood through linguistics where linguistics is the study of language. Linguistics produces language theories, this is different from children as language acquirers. Language acquisition in children cannot be understood by linguistics, but through psychology [11]. Therefore, a new discipline emerged called Psycholinguistics or Language Psychology. Psycholinguistics is a combination of psychology and linguistics that studies language behavior.

Psycholinguistics studies the language processes that occur in the speaker's brain and the listener's brain. Psycholinguistics produces a picture of the language that is processed in a person who is involved in communication. For example, how the language processing process occurs, what is the form of the unit, what is the meaning it contains, and how is the process of understanding the language. Psycholinguistics studies language processes that are concerned with abstract aspects and physical aspects. The abstract aspect is a linguistic system that is embodied in the symbols and rules that govern it. The physical aspect is the corpus of discourse produced by the speaker in certain situations. Theoretically, the main goal of psycholinguistics is to find a language theory that is linguistically acceptable and psychologically able to explain the nature of language and its acquisition. The scope of psycholinguistics is 1) the relationship between language and the brain, logic and thought; 2) language processes in communication: perception, production, and comprehension; 3) problems of meaning; 4) perception of speech and cognition; 5) language behavior patterns; 6) acquisition of first and 
second languages; 7) the language process in an individual is abnormal. So in other words, psycholinguistics explains the nature of the structure of language, and how that structure is obtained, used when speaking, and when understanding the sentences of the speech.

Language acquisition is a process that takes place for children who learn to master their first language or their mother tongue. Language learning is related to the acquisition of a second language, where the language is taught formally to children [12]. The stage of acquiring the first language in children is related to the period of language development of the child. Acquisition of the first language in children goes through several stages, including 1) the acquisition of competence and performance stages, 2) the semantic acquisition stage, 3) the syntactic acquisition stage and 4) the phonological acquisition stage [13]. Acquisition of phonology begins with the acquisition of basic sounds. Basic sounds in human speech are / b /, / a /, / i /, / u /, / e /, / o /, / m /, and so on. Furthermore, at the age of one, the child begins to fill in these sounds with other sounds. For example / p / is combined with / i / becomes pi / and / b / is combined with / b / becomes / ba /. When a child can produce sounds, over time, the child will be smarter at producing sounds. This condition is influenced by the child's environment, cognitive and speech tools.

According to Krashens and Bland [14] that the acquisition of a second language is divided into two parts, namely acquisition, and learning. Acquisition occurs accidentally where the child is exposed to a form of language for which they intuitively reach a pattern whereas learning is the acquisition of a second language occurring consciously or deliberately which focuses on its form and structure. Naturalistic types are mostly found in second language acquisition. This is because humans as social creatures will always interact with the surrounding environment [15]. Four factors determine children's second language acquisition, namely motivational factors, age, formal presentation, and first language factors of learners [15]. The acquisition of a second language is very unique to learn. The uniqueness that we can observe is in the realm of linguistics and culture. Various approaches in determining the goal of language acquisition such as nativism, behavioral, and cognitive approaches. These three are the essence of all the development of methods and techniques in every research. This approach also influences language acquisition research [16].

Acquisition of a second language can be carried out in two ways, namely the acquisition of a second language in a guided manner and the acquisition of a second language naturally. Guided acquisition of a second language, namely the language taught to students by presenting material that has been understood. The material depends on the criteria determined by the lecturer. The strategies used by a lecturer are following what is considered the most suitable for his students. Natural acquisition of a second language is the acquisition of a second language that occurs in daily communication, free from teaching or lecturer leadership. Students acquire a second language in their way. Interaction demands language communication and encourages language acquisition. Two important features of the natural acquisition of a second language are the occurrence of daily communication and freedom from deliberate systematic leadership.

The acquisition of a second language can come from any language, which is learned after the mother tongue [27]. The acquisition of a second language can also be referred to as a third, fourth language, and so on. However, according to [7] language acquisition is intended for the mother tongue (first language), not for the second language, and so on, because according to him language is innate. When a child is acquiring language, two processes that occur, namely the process of competence and performance. The process of competence is the human capacity to understand the language in an individual's core knowledge of their native language. The performance process is the actual use of language, including listening, speaking, thinking, and writing [7].

Competence in a second language can be developed by learning a language. Adults can take advantage of the means of acquiring natural language as do children. The characteristics of language acquisition include vocabulary, morphology, syntax, and phonology. Second language acquisition is the acquisition of language starting at or after the age of 3 or 4 years. The acquisition of a second language can be experienced by both children and adults. The main difference between the acquisition of a first language, and a second language, is that the acquisition of the first language is an essential component of the cognitive and social development of a child. Acquisition of a second language occurs after a child's cognitive and social development. Acquisition of first language and second language have similarities in the order of acquisition of grammar items. The second language learning process is influenced by three things, namely the effect on word order, the influence on the bound morpheme, and the influence of the first language.

Variety of types of language acquisition can be viewed from five points of view, namely based on form, 
sequence, amount, media, and authenticity. The acquisition of the first language includes terms of the first language, native language, mother tongue, main language, and strong language. Meanwhile, acquisition of a second language includes a second language, non-native language, foreign languages, second languages, and weak languages. Acquisition of first and second languages can be obtained together or at different times. Second language acquisition can be obtained at preschool age, at elementary school age, from the environment. Language acquisition is an unconscious process that they use language to communicate.

Several factors are supporting the success of second language acquisition learning, namely the conceptual model of language learning, language aptitude, inter, and intra linguistic difficulties in learning language acquisition and environmental factors. If these four factors are not fulfilled, language acquisition interference will occur. Interference is a language misuse that occurs in bilingualism's pronunciation due to their familiarity with more than one language, which is caused by language contact. According to Suwito [17], if two or more languages are used interchangeably by the same speaker, there will be a state of mutual contact. In every language contact, there is a process of mutual influence between one language and another. As a result, there will be interference both orally and in writing in the use of language. Interference can also occur due to insufficient language vocabulary in the face of progress and renewal. The disappearance of words that are rarely used, the need for synonyms, prestige in the source language, and lack of loyalty to the language of acceptance are factors that cause interference [18]. Interference is a change in a language system that is related to the contact of language with other language elements by bilingual speakers. Besides, interference occurs because of the habits of speaking the first language or mother tongue into the second language.

Language acquisition interference also often occurs among students. Students have studied Indonesian language lessons since elementary school. These mistakes occur in and outside the classroom. The fact shows that students still interference with in the use of language both orally and in writing. This happens because the lack of special attention to Indonesian language skills causes students to have no desire to learn to speak Indonesian properly and correctly. Moreover, students become objects to make changes and developments in the field of education. There are still many students who use their mother tongue to communicate. This situation often occurs in conditions of oral communication practice on campus.
Students often use Indonesian which is far from the Indonesian grammar when they communicate in class. Often the first language used by students will affect how they communicate.

The interference deviates from the determinants of communication and the rules of language that have been determined. There are several divisions of interference, namely 1) the phonological area, 2) the morphological area, 3) the syntactic area, and 4) the semantic area [19]. Phonological errors, namely errors in using phonemes and spelling. Morphological errors, namely misuse of affixations. Syntax errors, namely errors in sentence structure, word order, coherence, phrase arrangement, sentence cohesiveness, and sentence logic. Semantic errors, namely errors in understanding the meaning of words and the accuracy of using words in writing or writing sentences. Tarigan [20] states that interference often occurs in language learning, both in second language learning or in first language learning. Therefore, we need a procedure to reduce or eliminate interference among students.

There are several examples of both verbal and written interference, such as 1) The siblings hugged each other when they met to let go of their miss. 2) The little boy is riding the little bicycle that his father bought him. 3) The thief stole a motorcycle from the village head. 4) It would be nice if we have to do tutorial activities on websites that are credible and trusted so that they are safe if used as a reference for data from online. If you look at the example above, you can see that there are simple mistakes. However, this cannot be considered small because the aspect of language competence is very necessary for one's life. According to Suwito [17], the process of using language interchangeably by the same speakers can cause the language to be in a situation of language contact or mutual contact. According to Hidayat and Setiawan, interference occurs because the mastery of a language is more dominant or better than other languages. This condition will have a bad impact on students and the development of the Indonesian language. Darini [21] states that Indonesian language interference occurs due to background factors of familiarity and prestige.

Speaking Indonesian properly and correctly has to be done according to the situation and conditions. In formal situations, the correct use of Indonesian is a top priority. The use of Indonesian like this often uses standard language with its rules. Things that must be avoided in the use of standard language, namely the presence of language symptoms such as interference, integration, code-mixing, code-switching, and slang, which are often unwittingly 
used in official communications. This results in the Indonesian language being used not properly and correctly [22]. There are two forms of interference, namely dynamic interference and static interference. Dynamic interference is temporary interference as a result of speech production errors when language elements accidentally appear in another language series. Meanwhile, static interference is interference that has become part of the grammar of a bilingual [23]. The concept of language acquisition states that we have to get used to correct sentences [24]. Don't justify wrong sentences either verbally or in writing. Thus, language acquisition learning will determine the language competence of students.

Indonesia is always experiencing development and change due to social, economic, and cultural changes.

Language development occurs in the fields of science and technology as a result of contact in the fields of politics, economics, science, and others. The mutual influence between languages cannot be avoided because language is an integral part of the culture. According to Weinrich [10] language contact is an event that two languages that are used interchangeably by the same speaker. As a result of language contact, there is a transfer of language elements from one language to another which includes all levels. This causes the process of using and influencing other language elements to occur. In every language contact, there is a process of mutual influence between one language and another, resulting in interference both verbally and in writing.

Language interference and integration arise as a result of the existence of bilingualism due to their familiarity with more than one language, which is due to language contact. The insufficient vocabulary of a language in the face of progress and renewal can also cause interference [18]. Apart from that, the bilingualism of the speech participants and the lack of loyalty towards the recipient's language are also factors that cause interference. Interference is an error caused by the habit of pronouncing one language against another language including the pronunciation of sound units, grammar, and the vocabulary of Alwasilah [25]. Jendra [26] states that interference includes various aspects of language, namely the fields of a sound system (phonology), word formation (morphology), sentence structure (syntax), vocabulary (lexicon), and meaning (semantics). According to Nababan [29], interference is an error that occurs as a result of carrying out habits of mother tongue speech into the second language. Chaer and Agustina [10] argue that interference is an event of deviating the norms of several or more languages.
There are several opinions of experts on interference from sociolinguistics, namely First, according to Chaer [10] interference to changes in a language system is related to the contact of the language with other language elements carried out by bilingual speakers. Interference occurs because of deviations in using a language by entering another language system. The interference occurs due to the carrying out of the spoken habits of the mother tongue or dialect into the second language or dialect. Second, Abdulhayi [31] refers to the opinion of Valdman, which states that interference occurs due to the habit of using the mother tongue (first language) in the mastery of the language being studied (second language). As a result, there is a transfer or transfer of negative elements from the mother tongue into the target language. Third, Alwasilah [25] states that interference is a mistake caused by the tendency to accustom the pronunciation of a language to other languages including the pronunciation of sound units, grammar, and vocabulary. Fourth, Yusuf [32] states that interference occurs due to differences between the source language, target language, and vocabulary diversity. Fifth, Jendra [26] states that interference is a symptom of infiltrating a language system into another language. Interference occurs because bilingualism apply the sound unit system (phoneme) of the first language to the sound system of the second language so that there is a deviation in the phonemic system of the receiving language.

Interference is the greatest change and often occurs in language development. Symptoms of interference from one language to another are difficult to avoid and this condition cannot be separated from the behavior of the speakers of the receiving language. Bawa [28] argues that there are three main characteristics of language behavior, namely (1) language loyalty, namely the attitude of loyalty to language, (2) language pride, namely an attitude of pride towards the language that is owned, and (3) awareness of the norm, namely an attitude of being aware of language norms. The three main characteristics of language behavior must be possessed by a person so that interference does not easily occur. There are three main elements contained in the interference, namely the language of the source or donor language, the language of the recipient or the language of the recipient, and the presence of language elements that are absorbed of absorption elements [26]. When communicating, interference can occur reciprocally. The language that is the source at a certain time will change its role to the receiving language and so the receiving language can act as the source language. 
Interference is a symptom of speech that occurs in bilinguals and the event is considered a deviation. Interference is the biggest, most important, and most dominant symptom of language change in language [30]. Based on Hockett's opinion, it can be concluded that this linguistic symptom needs great attention because it can occur in all components of language, from the fields of sound, structure, grammar, grammar, and meaning.

\section{CONCLUSION}

Indonesian language acquisition learning has been studied from elementary school to university. However, there are still many interventions carried out by students and students. The results showed that there was a lot of interference among students both inside and outside the classroom. This interference cannot be considered small because aspects of language competence are very necessary for a person's life. The concept of language acquisition states that we have to get used to correct sentences. Don't justify wrong sentences either verbally or in writing

\section{ACKNOWLEDGMENTS}

The author would like to thank the Supervising Lecturer who has provided guidance and direction in writing this journal.

\section{REFERENCES}

[1] J. Z. \&. M. A. Maluleke, "Second Language Acquisition and Learning: Rethinking the Pedagogical Applicability of Stephen Krashen's Monitor Model.," International Journal of Social Research, pp. 4(50), 1-10., 2020.

[2] Rosdiana, "Language Acquisition: Classroom Language Acquisition for Preschool Students," Journal of English Language Teaching, pp. 1(1), 63-69., 2016.

[3] A. Derakhshan, "The Interference of First Language and Second Language Acquisition," Theory and Practice in Language Studies Journal, pp. ,5(10), 2112-2117., 2017.

[4] M. Hoque, "An Introduction to the Second Language Acquisition.," Journal of Learning and Teaching, pp. 3(4), 1-10., 2017.
[5] M. Nazir, Metode Penelitian, Bogor: Ghalia Indonesia, 2013.

[6] R. Prasetyowati, Pemerolehan Bahasa pada Masyarakat (Kajian Sosiolinguistik), Jakarta: Balai Pustaka, 2018.

[7] N. Chomsky, "Cartesian Linguistics A Chapter In The History Of Rationalist Thought (James Mcgilvray Ed.).," Cambridge University Press, 2009.

[8] T. F. B. d. S. U. N. Y. Musfiroh, "Diktat Kuliah. Pengantar Psikolinguistik," Yogyakarta, Fakultas Bahasa dan Seni, Universitas Negeri Yogyakarta, 2002.

[9] N. F. L. A. M. R. M. Ramirez, “ The Initial Stages of First-Language Acquisition," Journal of Child Language, pp. 40(2), 391-414., 2013.

[10] A. Chaer, Psikolinguistik: Kajian Teoretik, Jakarta: Rineka Cipta., 2003.

[11] Yudibrata, Psikolinguistik, Jakarta: Depdikbud PPGLTP, 1998.

[12] S. R. Fatmawati, "Pemerolehan Bahasa Pertama Anak Menurut Tinjauan Psikolinguistik," Lentera, pp. 18(1), 63-75., 2015.

[13] S. Ardiana and Sodiq, Psikolinguistik, Jakarta: Universitas Terbuka, 2000.

[14] S. \&. B. J. Krashens, "Compelling Comprehensible Input, Academic Language and School Libraries. Children's Literature in English Language Education,"” pp. 2(2), 1-13, 2014.

[15] Shafa, "Teori Pemerolehan Bahasa dan Implikasinya dalam Pembelajaran," Dinamika Ilmu, pp. 12(2): 1-9, 2017.

[16] R. R. Z. L. N. Pribadi, "The Influence of Family in Second Language Acquisition in Children Aged 1.5 Years: An Analysis of Monitoring Theory by Krashen," .Hortatori Jurnal Pendidikan Bahasa dan Sastra Indonesia, pp. 3(1), 22-30., 2019.

[17] S. Cipta., Pengantar Awal Sosiolinguistik: Teori dan Problema, Surakarta: Henary, 1985.

[18] Sukardi, "Interferensi Sintaksis Bahasa Indonesia Ke dalam Bahasa Jawa dalam Majalah Mekar Sari: 
Sebuah Studi Kasus," Widyaparwa: Jurnal Ilmiah Kebahasaan dan Kesastraan, pp. 53, 111-121, 1999.

[19] M. \&. S. A. Press., Analisis Kesalahan \& Karakteristik Bentuk Pasif., Surakarta: Muhammadiyah University, 2014.

[20] H. G. Tarigan, Pengajaran Analisis Kesalahan Berbahasa., Bandung: Penerbit Angkasa., 1988.

[21] S. Darini, “ Interferensi Fonologi, Morfologi, Dan Leksikal Dalam Komunikasi Formal Mahasiswa Sastra Indonesia Fakultas Ilmu Budaya Universitas Airlangga, Skriptorium," pp. 1(3), 615., 2013.

[22] R. P. Suminar, "Pengaruh Bahasa Gaul Terhadap Penggunaan Bahasa Indonesia Mahasiswa Unswagati," Jurnal Logika, pp. 18(3), 143-148., 2016.

[23] N. a. Syuhda, "The Interference of Malay Language Towards The Indonesian Language," Lingua Didaktika , pp. 13(1), 11-25., 2019.

[24] R. \&. S. K. K. Devilito, "Peran Pembelajaran Linguistik (Bahasa) untuk Meminimalisasi Kesalahan Pemakaian Bahasa Oleh Mahasiswa (Studi Kasus Analisis Kesalahan Berbahasa)," Jurnal Linguistik,, pp. 2(4), 1-7., 2018.

[25] A... C. Alwasilah, Beberapa Madhab dan dikotomi Teori Linguistik, Bandung: Angkasa, 1985.

[26] J. I. W. Ikayana., Dasar-Dasar Sosiolinguistik, Denpasar, 1991.

[27] Ellis, R. (1997). Second Language Acquisition. Oxford: Oxford University Press.

[28] Bawa, W. 1981. "Bahasa dan Sastra". Nomor 6, tahun VII. Jakarta: Pusat Pembinaan dan Pengembangan Bahasa

[29] Nababan, P.W.J. 1984. Sosiolinguistik Suatu Pengantar. Jakarta: PT. Gramedia Pustaka Utama

[30] Suwito. 1983. Sosiolinguistik Teori dan Problema. Surakarta: Fakultas Sastra dan Seni Rupa.

[31] Abdulhayi. 1985. Interferensi Gramatikal Bahasa Indonesia dalam Bahasa Jawa. Jakarta. Departemen Pendidikan dan Kebudayaan.
[32] Y. Y. Yusuf, M. Sarhadi and A. Gunasekaran. Agile manufacturing:: The drivers, concepts and attributes. International Journal of Production Economics, 1999, vol. 62, issue 1-2, 33-43 